\title{
Innovative Research on Training Mode of Tourism Management Talents under the Trend of "Intelligent Tourism"
}

\author{
Shuangfan Song \\ Hubei University of Science and Technology \\ Xianning, China
}

\begin{abstract}
As a new form of tourism development in China in the new era, smart tourism has realized the transformation of tourism industry. In the continuous development of industry, people also put forward higher requirements for personnel training. Therefore, as a tourism management major, we must actively strengthen personnel training mechanism, increase the education of tourism professionals, and actively realize the innovation of personnel training mode, and build more modern talents training system, so as to provide more talents for the society. This paper will make a scientific analysis on the effective innovation of the training mode of tourism management professionals under the trend of intelligent tourism.
\end{abstract}

Keywords-intelligent tourism; tourism management specialty; innovation of talent training model

\section{INTRODUCTION}

Under the trend of smart tourism, big data, mobile Internet and Internet of Things have all been widely used. With the use of network facilities, various kinds of travel information have been obtained in time, so that they can correctly perceive various travel information and effectively realize the integration of tourism service, tourism experience and tourism marketing, having promoted the stable development of the tourism industry. Under the knowledge economy, science and technology have become the primary productive forces [1]. Under the premise of the flourishing development of modern information technology, people's lives, work, production, and other activities are all more convenient. Therefore, information technology has played a good role in promoting progress development of our society. High-tech is the product of the era. With the trend of smart tourism, more and more advanced technologies are being applied to the tourism profession. Through the use of cloud computing and big data, we have achieved reasonable development and utilization of resources related to tourism professionals, and at the same time, people's diverse tourism need have been better satisfied. The concept of smart tourism was put forward in 2011. Its main purpose is to realize the optimization of China's tourism professional services and make it a booster for the service industry. Beijing is one of the national pilot cities for smart tourism. Therefore, we must pay attention to the construction of talents, take the cultivation of high-quality talents as the core content of tourism management work, build an effective tourism professional training goal, establish a networked tourism professional management platform, and intensify the innovation of talent training [2]. It is necessary to provide timely personnel protection starting from the actual conditions so that China's tourism industry can better adapt to the development of the times.

\section{RESEARCH ON THE RISE OF INTELLIGENT TOURISM}

The concept of intelligent earth was put forward in 2008. Then, it was paid attention to by the people of all walks of life and was followed by industrial capital. Gradually, the concept of intelligence has been infiltrated in people's life and production, involving many areas such as urban construction and social life. Therefore, the concept of smart tourism arises at the historic moment, and has also become a hot topic of tourism research. China's research on the concept of smart tourism started late and it is mainly used in construction strategies and application values. More and more people have affirmed technologies such as Internet of things and big data, making these technologies become an important technical support for the development of smart tourism. The value of smart tourism is mainly embodied in the aspects of information communication and transmission with gradually realizing information sharing. With the aid of navigation, shopping guides and other functions of mobile devices, tourists have experienced the uncanny workmanship of nature and mastered the situation of a foreign country, which supports people to effectively be free from the limitations of time and space. For the better development of smart tourism, people established a public information platform for tourism information in a timely manner, and added these items: transportation consulting, tourism transactions, tourism information consulting [3], hotel management, scenic area management, etc., and formulated a warning system for tourism disasters. All these measures have enormously promoted the further improvement of the function of smart tourism services. In 2012, the state departments announced the "National Smart Travel Pilot City" and clarified the pilot units of the national smart tourism scenic spot, which allowed these pilot cities to play a good leading role. Through remote navigation, informative area management, and tourist self-help centers, smart travel has taken an important position in people's hearts. In 2015, the National Tourism Administration 
proposed the "Guiding Opinions on Promoting the Development of Smart Tourism" [4]. At the same time, it put forward: smart tourism is the main way to improve the rapid development of China's tourism industry and actively realize the successful transformation of it. Therefore, we must respond to the call of the country and proceed from the satisfaction of tourists to fully reflect the modernization of the tourism industry.

\section{THE NEW REQUIREMENTS OF INTELLIGENT TOURISM ON THE DIRECTION OF PERSONNEL TRAINING}

As a new form of tourism development in China, smart tourism is also an inevitable trend of social development. It is not only a simple information technology, but also an effective combination of tourism and modern technology and great attention to the real experience of tourists, which fully reflects the difference between tourism management and tourism service. The trend of smart tourism makes innovation in the training model of tourism professionals more urgent [5]. This is also the inevitable way for tourism professionals to achieve sustainable development.

\section{A. Cultivate Professional Talents with the "Internet +" Thinking Model}

Smart travel must conform to the future form of the Internet and can be applied to various terminal platforms, desktops, notebooks, tablets, mobile phones, watches, glasses, etc., allowing the Internet industry to actively integrate physical industries. In the new era, smart tourism talents are required to have these qualities: they have good professional ethics and legal awareness, and they can obtain information technology in accordance with the law; they can skillfully operate advanced technologies such as the Internet and cloud computing to provide more talent reserve services for tourism businesses. By using professional technology to quickly identify all kinds of business information, make full use of the efficiency of information and solve practical problems in time, we can greatly improve the satisfaction of tourists, so that we can also achieve the goal of value-added tourism business.

\section{B. Improve the Application Ability of Software and Hardware Involving Information Technology}

Since smart tourism is built on the basis of information technology and meets the diversified needs of tourists by adopting a holistic approach, the ultimate goal of promoting the rapid development of tourism management expertise is achieved finally [6]. Therefore, it can be said that smart tourism is a higher level of tourism informatization. Under the rapid development of smart tourism, tourism management professionals must constantly increase the training of skilled personnel and attach importance to the training of tourism professional talents. Under the trend of smart tourism, personnel are required not only to have a solid theoretical knowledge, but also to skillfully operate the relevant new equipment and facilities. Meanwhile, using advanced technologies as material carriers is also necessary, because all marketing and services need to be implemented by using new equipment. For example, smart hotels, smart resorts and other constructions are inseparable from modern technologies such as WeChat. Therefore, relevant personnel are required to have innovative thinking, solid theoretical knowledge, and be able to provide a scientific reference for the future development of the tourism industry.

\section{Cultivate Professionals Who Meet the Development Needs of the Industry}

Under the trend of smart tourism, China's tourism management professional training mode has also undergone some changes. For tourists, the quality and individuality of tourism services are of vital importance. This is also the main embodiment of the professional management level of tourism management in China. Therefore, it is imperative to actively update the knowledge structure, optimize and adjust it in a timely manner so that it can play a good role as the catalyst, thus meeting the modern tourism model. China's tourism industry has also experienced rapid development for a long period of time. This development mainly comes from the demographic dividends, policy dividends, and economic development dividends. But when these effects are gradually weakening, there is only cost advantage left. But unfortunately, our cost advantage is also suffering slow weakening. When we have neither cost advantage nor core technology, we need to provide better services, which is the origin of the tourism market and customer needs. Accordingly, it is imperative to cultivate suitable talents truly surrounding the needs of customers.

\section{INNOVATIVE ANALYSIS OF THE TRAINING MODEL OF} TOURISM MANAGEMENT PROFESSIONALS UNDER THE TREND OF SMART TOURISM

\section{A. Innovative Ideas for the Training of Tourism Management Professionals}

1) Specific tasks for personnel training: We should actively cultivate talents of comprehensive development in morality, intelligence, physical education, beauty, and labor; adopt world-oriented management methods; focus on tourism product production, planning, marketing, service, etc.; master service skills and possess the basic qualities of tourism management professionals and be awareness of service, capable of high-star hotel, guide service, travel agency, tourism administration and other service work, becoming composite tourism professionals of high-quality, high skill level, comprehensive ability.

2) Culture qulifications: What we have cultivated should be such talented people: they have a clear political orientation, love the motherland, have a sense of service, and consciously study the spirit of the Nineteenth Congress and Deng Xiaoping Theory, and form a correct outlook on life and values in a timely manner. In daily life, they need to be honest, responsible, and innovative. Moreover, talents need social adaptation ability, good communication skills and coordination ability, team cooperation consciousness, advanced thinking and active thinking, which are accompanied by quickly adapting to the enterprise production and services, and actively contributing their own strengthens 
in the front line, bringing greater economic benefits to the enterprise. Having a certain amount of military basic knowledge and good lifestyle habits, paying attention to daily exercise are also in demand. What's more, talents should set strict requirements on themselves, ensure a sound psychological quality, and constantly improve the aesthetic sense. It will be better for them to obtain qualification certificates during the service process, such as: National Tour Guide Qualification Certificate, Personnel Skill Certificate on Catering Service, Intermediate Skills Certificate on Front Office Service, etc.

\section{B. Innovative Measures for Talent Cultivation}

1) Clarify the development situation of tourism: To do a good job of their own requires that we must clarify the current status of the development of smart tourism in China and recognize the current situation in the process of personnel training. As a new technology, the main purpose of smart tourism is to better meet the diversified needs of tourists, actively achieve the level rise of tourism services and the tourists' satisfaction, and effectively realize the rational use of tourism resources and information sharing. From the ideological point of view, it is necessary to recognize the necessity of professional training of tourism management professionals. First of all, we must clarify the current status of tourism services and actively carry out innovations in tourism management models. For example, putting advanced technologies, such as, communication technology and intelligent technology into use and especially in the tourism management process, making it quickly become part of smart tourism. Under the leading role of government departments, we must formulate long-term tourism development strategies in a timely manner, define development goals, and, constantly accelerate the pace of development of the tourism industry with the strong support of national policies and conscientiously implement strategic deployment. In the process of gradually advancing the strategic objectives, we should strengthen the timely optimization and adjustment of the development plans for smart tourism, proceed from the actual situation, and base itself on the present so as to effectively promote the smooth progress of tourism informatization operations. And at the same time, effective improvement of the public services consciousness and professionalism level of the tourism industry should come into true, finally leading to the formation of a group of smart tourism cities that playing a leading role and taking an advantageous position in the modernization of tourism.

2) Actively establish people-oriented management awareness: The emergence of the emerging industry of smart tourism has made the tourism management profession face certain challenges. Therefore, to promote the smooth progress of the professional training of tourism management professionals, it is necessary to reorient the personnel roles [8] to ensure that the trained personnel are in compliance the development need of the times and are capable of providing practicable advices for the future development of the tourism industry. Starting from the current actual conditions, we shall formulate an effective talent training mechanism; actively carry out innovative personnel training models, and pay attention to the training effect and quality of tourism personnel. In the meantime, we will consciously establish a people-oriented management concept, clarify the needs of talented people, and promote the full play of the timeliness of tourism personnel training.

3) Enterprises must participate in the process of personnel training: Schools and enterprises should establish friendly cooperative relations, strengthen cooperation, establish a networked, intelligent travel cooperation platform, and cultivate talents needed by enterprises. They need to jointly explore innovative ideas for the training of tourism management professionals, attach importance to the development of new talents and vigorously promote the construction of teaching software and hardware facilities, and strive to build a strong professional talents team for intelligent tourism management. There is another task that promoting teacher curriculum reform and talent training work in an orderly progress as well as innovating the teaching model. Taking various measures, such as task driven, on-site teaching and online learning, to train more high-quality and skilled talents for our tourism management major to inject vitality into the better development of tourism is another measurement for growing intelligent tourism.

4) Take capacity development as the core content: We should pay attention to the cultivation of the professional ability of tourism management students, and take the ability training as the core, so as to effectively improve the professional level of students. Under the trend of smart tourism, students in tourism management are required not only to have certain theoretical knowledge, but also to be able to flexibly use what they have learned and be compound talents. Taking the ability training as the core should be accompanied by conducting a market research on the demand of talents for tourism enterprises under the trend of smart tourism at the same time. According to the demand level of talents, based on the actual situation of schools, we have identified the main objectives of training students' professional ability. Besides that, having comprehensive grasp of the specific contents of personnel training and skills that teachers need to master, appropriately increasing the proportion of information technology in teaching on the basis of professional courses, building supporting personnel training facilities, and providing hardware facilities also are of vital. At the same time, a smart tourism scenario simulation platform has been established and under the premise of applying information technology, the service ability of tourism management students has been greatly improved.

5) Adopt dual-teacher management methods to improve teaching quality: Under the trend of smart tourism, students of tourism management must not only have a solid theoretical foundation, but also must consciously make good knowledge 
reserves and pay attention to the improvement of their own practical ability, and build a dual-qualified talent team. The tourism management professional school should start from the students' needs and actively introduce some high-quality and senior personnel. It is necessary for them to adopt a combination of internal management and external introduction to create a more professional dual-teaching team for tourism professional and make full use of modernization to reflect the advantages of computers, multimedia and simulation technology in a timely manner. Conscientiously analyzing the main problems in current teaching, encouraging students to consciously study network technology, and strengthening the absorption and digestion of teaching content play irreplaceable roles in prompting students to quickly become familiar with the online service, tourism marketing and other operational processes. All these steps serve to not only lead to effective promotion of teachers of tourism management specialty, but also lay a stable foundation for the development of smart tourism.

6) Constructing the teaching system of the integration of the course and certificate: To regard improve students' skill as the ultimate goal is the focus of the work of tourism management professional personnel training. So, we should pay attention to the professional tourism management curriculum development efforts, fully consider the occupation post demand in the process and timely refer to the occupation qualification standards timely to optimize the content of curriculum reform effectively. The curriculum reform should be divided into two parts: modern hotel management and travel agency management. In addition, the travel agency management includes basic knowledge of tour guides, travel planning, tour guide services, social etiquette and many other contents. It also includes Chinese tourism geography and tourism psychology, local culture, national tour guide qualifications, etc. At the same time, we must clarify the management content of modern hotels, such as: Introduction to hotel management, room management, and catering intermediate certificate management, etc. The curriculum content will be divided into modules, and then the corresponding contents of each module will be timely integrated into the curriculum reform of tourism management. The relevant standards for qualification certificate of tourist guide should be incorporated into the tourism management process, from service to management, and effectively promote the orderly implementation of curriculum reform in tourism management through constructing of a management system of integrating curriculum and certification.

\section{CONCLUSION}

Under the trend of smart tourism, China's tourism management professional actively has been carrying out management model innovation and has realized the real transformation of China's tourism industry. In the training of talents, full consideration has been given to the degree of demand for talents from the enterprise. Starting from the actual conditions, a reasonable and effective training mechanism for talents has been established and innovative teaching measures for the teaching of tourism management have been innovated. By consciously establishing service awareness, renewing management concepts, and combining tourism management professional theories and practical content in time, and integrating curriculum and certification, the curriculum reform has been going through smooth implementation.

\section{REFERENCES}

[1] Zuo Xiaojuan, Yu Yong, "Innovative Research on Training Mode of Tourism Management Talents under the Trend of "Smart Travel"' J. Journal of Taiyuan Urban Vocational College, 2016(4), pp.137-138.

[2] Liu Yudi, "Research on the innovation of undergraduate talents training mode of Tourism Management Specialty under the background of Intelligent Tourism” J. Journal of Jiamusi Education Institute, 2016(4), pp. $24-24$

[3] Liu Yixue, "Research on the innovation of OPEC talents training mode of tourism management major from the perspective of Intelligent Tourism" J. China Collective Economy 2016(22), pp.150-152.

[4] Wei Jiufeng, "Research on Applied Undergraduate Tourism Management Professionals Requirement and Training Mode under the Background of Smart Tourism" J. Human Resource Management, 2016(4), pp.148-149.

[5] Liu Hailong, "Introduction to the effective innovation of the training mode of tourism management professionals under the trend of "intelligent tourism"'” J. Silk Road Vision 2017(26),pp.25-25.

[6] Hu Xiaocong, "Investigation into the training mode of tourism talents under the background of "Internet plus " J. Business Economy, 2015(10), pp.70-71.

[7] Liu Baiping, Ping Ren, Ling Tang, " Research on the "ProfessionalEntrepreneurial" Tourism Personnel Training Model under the Background of "Double Creation"'” J. Modern Business Trade Industry, 2016, 37(19), pp.177-178.

[8] Sun Likun, Wei Xiaoming, "Construction of undergraduate course system for tourism management under the background of smart tourism” J. The South Journal, 2017(10), pp.83-84. 